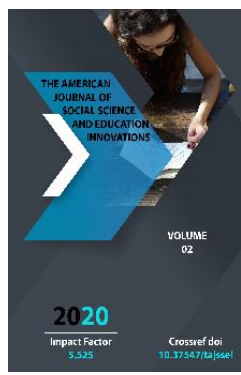

\title{
Comparative Analysis Of Uzbek And English Proverbs
}

\author{
Ahmedov Umidjon \\ Lecturer Of Kokand State Pedagogical Institute, Uzbekistan
}

Copyright: Original content from this work may be used under the terms of the creative commons attributes 4.0 licence.

\section{ABSTRACT}

Every language has its own stock of proverbs and proverbs in one language today reflect every age and time. The proverbs show us as the observation of everyday life, constitute popular philosophy of life, and provide an insight into human behavior and character. This article discusses comparative analysis of Uzbek and English proverbs.

\section{KEYWORDS}

Proverbs, sayings, translation, equivalent, comparative analysis of Uzbek and English proverbs

\section{INTRODUCTION}

The proverbs are popularly defined as short expressions of popular wisdom which refer to common experience are often expressed in metaphor, alliteration, or rhyme. A proverb (from the Latin proverbium) is a simple and concrete saying popularly known and repeated, which expresses a truth, based on common sense or the practical experience of humanity (Latin, 2011). The linguist W. Mieder defines a proverb in his book: "A proverb is a short, generally known sentence of the folk which contains wisdom, truth, morals, and traditional views in a metaphorical, fixed and memorisable form and which is handed down 
from generation to generation" [1, p. 27]. It is clear from the definition that proverb is not a simple unit of a language; it is a ready-made sentence that gives metaphorical meaning with words of wisdom or traditional thoughts of people or nation.

\section{MATERIALS AND METHODS}

The proverbs of each country are different from one another, depending on the history of creation and the ways which people express in their lifestyle. There are similarities between proverbs in English and Uzbek. This attitude is that when we analyze proverbs in various ways [Palmer, 1981]:

1. Morphological;

2. Lexical;

3. Etiological;

4. Stylistic.

We can clearly see differences between them in the analysis. One of the first differences between the two languages is the images used in them. In many English proverbs, the expression of human nature is often used by animal images:

Eagles do not catch flies (eagles do not hold flies).

The higher the monkey climbs the more he shows his tail (the more the monkey looks up, the more tail it looks)

In contrast, Uzbek proverbs refer as a simple human lifestyle without getting an animal image. For instance:

-O'xshatmasdan uchratmas (They do not meet who do not look like each other).

Here, we should mention a few variations in translating proverbs from one language into another. It helps to translate proverbs from the English language to the Uzbek language through these types of translation. There is equivalent form of the above mentioned Uzbek proverb in English: O'xshatmasdan uchratmas (They do not meet who do not look like each other)- Birds of a feather flock together.

There are several types of proverbs that can be translated into other languages [1]:

> Using phraseological Equivalent;

$>$ Absolute Equivalent;

$>$ Similar Equivalent.

$>$ Use direct translation

There are the same proverbs in English and Uzbek which can be translated into absolute style.

A watched pot never boils - Kutilgan qozon qaynamas.

Wisdom is the beauty of men - odam bezagi aql (beauty of man is his wisdom).

Manners make the man - insonni fazilatlar ulug'laydi (Manners earns reputation for man).

\section{RESULTS AND DISCUSSIONS}

There are some types of English proverbs that cannot be translated into Uzbek directly. In this case, we need to find and translate proverbs in this language in Uzbek.

A rotten apple spoils the barrel- Tirriq qo'zi podani buzar (thin lamb spoils the herd).

A proverb in the English language that a badtempered person can be influenced by the whole group is "spoilt apple" in English, but in 
the same meaning the Uzbek proverb says that "thin lambs destroy the herd."

There are a few examples of this proverb: A fool at forty is a fool forever - Qari bo'lgan bilan dono bo'lmas (Although man becomes older he will not be wise).

In some proverbs, since the Uzbek-language lexis does not exist in English, they are translated into English language by explaining them so that the proverb may not be equivalent or analogous:

There is Uzbek proverb which embodies the wisdom of women's entrepreneurship, wisdom and ingenuity.

"erni er qiladigan ham, yer qiladigan ham xotin" (meaning: A good wife makes a good husband, a bad woman makes a bad husband).

..."erni sher qiladigan pul, xotinni sher qiladigan hushtor" Money that makes man like a lion and money makes a woman like a lioness."

In the drama "Kelinlar qo'zg'aloni" of Said Akhmad (Bride's Revolt) Bashorat speaks along with Uzbek proverbs

"So'z ko'rki maqol" (a speech-a proverb), "bir tovuqqa ham don kerak, ham suv kerak" (One chicken needs both grain and water)

"zo'rdan zo'r chiqsa, zo'r bo'ynini egar" (On the strong there is a stronger), "kichkina demang bizni, ko'tarib uramiz sizni" (never judge looking at the appereance),

"Eskini yamasang, esing ketadi" (You'll make something fit out of the old, exhausted), "qudachilik - ming yilchilik" (mutual relationship lasts thousand years between the relatives of bride and bridegroom)

Most of the Uzbek proverbs express relationship to life, a response to reality and a sense of reflection.

\section{CONCLUSION}

In conclusion, we can mention that there are some proverbs which are very difficult to translate, in some cases almost impossible, as they are narrowly linked to the cultural and social system of the society. Comparison of two nations' proverbs reveals that proverbs reflect the rich historical experience of the people, ideas which related with work, lifestyle and culture of people. Using proverbs correct and appropriate makes speech unique originality and the expressiveness.

\section{REFERENCES}

1. Mieder W. International Proverb Scholarship. New York: Garland Publishing, 1993. P. 27-63.

2. Sayyid Ahmad. Selected works, 3 vols. Tashkent: G. Gulom Publishing House of Literature and Art. 1982.

3. Yusupov U.K. Contrastive Linguistics of the English and Uzbek languages. Tashkent: Akademnashr, 2013. P. 27262.

4. Norrick N.R. How proverbs mean. Berlin: Mouton, 1985. 13. Taylor A. The proverb and index to "the proverb". Hatboro/ PA: Folklore Associates, 1962.

5. Muhamadjonovna, S. D. (2020). The key concepts of forming sociolinguistic competence of future English language specialists. Asian Journal of Multidimensional Research (AJMR), 9(5), 118-121. 
6. Muhamadjonovna, S. D. (2020). The development of sociolinguistic competence of future English language teachers through computer technologies. European Journal of Research and Reflection in Educational Sciences, 8 (3) Part II, 147-150.

7. Sarimsakova, D., \& Rashidova, S. (2017). DEVELOPING INTERCULTURAL COMPETENCES WITH CASE STUDIES. In WORLD SCIENCE: PROBLEMS AND INNOVATIONS (pp. 212-214).

8. Sarimsakova, D. (2019). Communicative competence as a result of EF teaching and learning ISJ Theoretical \& Applied Science, 12 (80), 166-169 https://dx. doi. org/10.15863. In TAS (Vol. 80).

9. Toshpulatova, D. (2019). РОЛЬ МЕНТАЛЬНОЙ АРИФМЕТИКИ В ПОВЫШЕНИИ МАТЕМАТИЧЕСКОЙ ГРАМОТНОСТИ В НАЧАЛЬНОЙ ШКОЛЕ. Theoretical \& Applied Science, (12), 184-186. 